\title{
Pengaruh Pemberian Naungan Terhadap Aklimatisasi Planlet Strowberi Varietas Dorit dan Varietas Lokal Berastagi
}

\author{
The Effect of Shading on Acclimatization of Strawberry Plantlets of Dorit and Local \\ Varieties of Berastagi
}

\author{
Hasim Ashari ${ }^{1}$, Zainuri Hanif ${ }^{2}$ \\ ${ }^{1,2}$ Balai Penelitian Tanaman Jeruk dan Buah Subtropika
}

\begin{tabular}{l}
\hline ARTICLE INFO \\
\hline Article history: \\
DOI: \\
10.30595/pspfs.v2i.188 \\
Submitted: \\
July 29, 2021 \\
Accepted: \\
Sept 10, 2021 \\
Published: \\
Nov 10, 2021 \\
\hline
\end{tabular}

Keywords:

Shading, Acclimatization, Strawberry, Dorit, Local Berastagi

\begin{abstract}
Strawberry plant tissue culture techniques have been successful in plantlet propagation. In order to produce strawberry seeds that are ready for planting, plantlets must go through the acclimatization stage. A modified growing environment with a plastic hood or housing needs to be considered to provide optimal environmental conditions for the acclimatization of strawberry plantlets. This study aimed to describe the effect of shading and type of variety on plantlet acclimatization of the Dorit variety and the local Berastagi variety. This research was experimental with RAK using 2 factors, namely shade with the plastic thickness of 0.17 $\mathrm{mm}$ and $0.12 \mathrm{~mm}$ and types of local varieties of Berastagi and Dorit varieties. Parameters observed were climate data, vegetative growth (percentage of plantlets growing, number of stolons, diameter of stolons, number of leaves). The data were analyzed with Anova 2 factors; if the results were significant, it would be continued with Duncan's test. The results showed that the shade had a significant effect on the growth of strawberry plantlets. In contrast, the variety had a significant effect on the vegetative growth of strawberries, and the variety with the best growth was the Berastagi variety.
\end{abstract}

This work is licensed under a Creative Commons Attribution 4.0 International License.

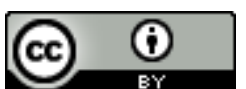

\section{Corresponding Author:}

Hasim Ashari

Balai Penelitian Tanaman Jeruk dan Buah Subtropika

Jl. Raya Tlekung no 1. Junrejo Batu, Jawa Timur

Email: hasimmuda@gmail.com

\section{PENDAhuluan}

Sektor pertanian sangat penting bagi kehidupan, karena berperan untuk memenuhi kebutuhan dalam bidang pangan. Tanaman stroberi merupakan salah satu komoditas tanaman buah-buahan yang permintaan pasar cukup tinggi di Indonesia. Stroberi merupakan tanaman C3 yang tumbuh baik pada cahaya dengan intensitas cahaya rendah terutama dataran tinggi yang beriklim basah.

Perbanyakan stroberi melalui kutur jaringan mampu menghasilkan tanaman clone dan mengeliminasi penyakit dari tanaman induk serta tanaman yang dihasilkan mempunyai keragaman genetik yang lebih tinggi. Salah satu keberhasilan kultur jaringan adalah teknik aklimatisasi yang mampu menghasilkan pertumbuhan dan produksi yang optimal. Stroberi dapat dikembangbiakkan secara konvensional dengan stolon. Untuk komersialisasi, cara ini tidak cocok karena tranfusi penyakit dari tanaman induk ke anakan, serta jumlah bibit yang dihasilkan terbatas (Mozafari, 2012). Kultur jaringan merupakan salah satu metode perbanyakan tanaman yang mempunyai beberapa keunggulan, yaitu dapat menghasilkan tanaman (clone) dalam jumlah yang besar, 
mampu mengeliminasi penyakit pada tanaman serta tanaman yang dihasilkan mempunyai keragaman genetik yang lebih tinggi dibandingkan dengan tanaman yang berasal dari benih (Shohael, 2008).

Daya tumbuh tumbuh pada saat di budidayakan dilapang seringkali mengalami kendala, yaitu tanaman belum bisa beradaptasi dari lingkungan yang terkendali ke lingkungan tak terkendali. Hal lain yang tidak kalah penting dan menentukan keberhasilan dalam pengembangan bibit stroberi secara in vitro adalah proses aklimatisasi, yaitu pemindahan tanaman dari lingkungan in vitro yang terkendali ke lingkungan yang lebih alamiah. Dalam aklimatisasi, lingkungan tumbuh (terutama kelembaban) berangsur-angsur disesuaikan dengan kondisi lapangan (Mariska dan Sukmadjaja, 2003).

Aklimatisasi bertujuan untuk mempersiapkan planlet agar siap ditanam di lapangan. Tahap aklimatisasi mutlak dilakukan pada tanaman hasil perbanyakan secara in vitro karena planlet akan mengalami perubahan fisiologis yang disebabkan oleh faktor lingkungan. Hal ini bisa dipahami karena pembiakan in vitro (dalam botol) semua faktor lingkungan terkontrol sedangkan di lapangan faktor lingkungan sulit terkontrol (Yusnita, 2003).

Lingkungan tumbuh yang dimodifikasi dengan sungkupan atau rumah plastik perlu dipertimbangan untuk memberikan kondisi lingkungan yang optimal bagi pertumbuhan stroberi. Tujuan dari penelitian ini adalah untuk mendeskripsikan pengaruh pemberian naungan dan jenis varietas terhadap aklimatisasi planlet tanaman stroberi varietas Dorit dan varietas Lokal Berastagi dan untuk mengetahui varietas stroberi yang paling baik pertumbuhannya.

\section{METODE PENELITIAN}

Pada penelitian ini menggunakan jenis penelitian eksperimental. Waktu pelaksanaan penelitian selama 5 bulan yaitu Februari sampai Juni 2019 di Kebun Percobaan Sumber Brantas, Balitjestro Batu Malang. Alat dan bahan yang digunakan diantaranya adalah timbangan digital (gram), hand refraktometer (ATAGO N-1 $\alpha$ Brix 0 $32 \%$ ), hygrometer (alat pengukur kelembaban dan suhu), alat pengukur $\mathrm{pH}$ meter, bibit tanaman stroberi dari V1 (planlet) kultur jaringan dengan 2 varietas (Lokal Berastagi dan Dorit) masing-masing varietas berjumlah 45 polibag, plastik naungan dengan ketebalan $0,17 \mathrm{~mm}$ dan $0,12 \mathrm{~mm}$, media tanah ladekan, pupuk organik (pupuk petroganik), kertas label, pupuk NPK, pupuk kasirit (Mg), kantong plastik, plastik polibag dengan diameter 10 $\mathrm{cm}$ dan $50 \mathrm{~cm}$.

Langkah kerja yang dilakukan dengan persiapan bibit tanaman stroberi, persiapan media tanam, penataan tempat penanaman, persiapan pembuatan sungkupan dan tahap perawatan. Pada tahap persiapan bibit tanaman stroberi berasal dari bibit dari aklimatisasi planlet, ditanam menggunakan polibag ukuran diameter $10 \mathrm{~cm}$ dibiarkan \pm 1 sampai 2 minggu sampai tumbuh akar putih sampai dasar polibag. Komposisi media yang digunakan 7 tanah ladekan : 2 sekam : 1 pupuk petroganik. Penataan tempat penanaman stroberi dibuat zig zag hal ini dibuat supaya produksi CO2 lebih banyak dan sirkulasi lebih optimal jika dibandingkan tanaman diletakkan berjejer. Pembuatan sungkupan dengan memasang pegangan dari besi untuk meletakkan plastik naungan, tinggi sungkupan 1 meter dari tanah dan pada tahap perawatan penyiraman dilakukan selama 1 minggu sebanyak 3 kali, pemupukan NPK 2 minggu sekali dengan dosis 2 gram/liter.

Pengambilan data dilakukan dengan cara tidak merusak tanaman. Pengamatan dimulai setelah 1 minggu setelah tanam dan dilakukan setiap 1 minggu 1 kali jika sudah produksi buah pengamatan dilakukan 1 minggu 3 kali. Pengambilan data dilakukan pada bulan februari sampai Juni dengan mengamati data iklim, persentase pertumbuhan planlet, pertumbuhan vegetatif (jumlah daun, jumlah stolon) dan brix .

Analisis data menggunakan RAK 2 faktor dan Anava 2 faktor, jika hasilnya signifikan maka akan dilanjutkan dengan uji Duncan dengan taraf kepercayaan $5 \%$. Data yang diperoleh dianalisis menggunakan Anava 2 arah.

\section{HASIL DAN PEMBAHASAN}

Penelitian pengaruh pemberian naungan terhadap pertumbuhan tanaman stroberi varietas Lokal Berastagi dan Dorit mendapatkan data yang meliputi kondisi lingkungan mikro, persentase tumbuh planlet, jumlah daun, jumlah stolon, diameter stolon dan produktivitas stroberi. Berikut ini hasil penelitian pengaruh pemberian sungkup pada aklimatisasi planlet sampai produksi buah.

Tabel 1. Rerata data suhu, kelembapan, intensitas cahaya dan $\mathrm{pH}$ pada macam perlakuan.

\begin{tabular}{lccc}
\hline \multirow{2}{*}{ Parameter } & \multicolumn{3}{c}{ Perlakukan } \\
\cline { 2 - 4 } & Kontrol & I & II \\
\hline Suhu $\left({ }^{\circ} \mathrm{C}\right)$ & $18-27$ & $18-25,5$ & $18-25,5$ \\
Kelembapan $(\%)$ & 66 & 67 & 74 \\
Intensitas Cahaya & 823 & 625 & 668 \\
$\mathrm{pH}$ & 7,3 & 7,7 & 7,5 \\
\hline
\end{tabular}

Proceedings homepage: https://conferenceproceedings.ump.ac.id/index.php/pspfs/issue/view/9 
Dari tabel 1. Menunjukkan bahwa perlakuan kontrol tanpa naungan mempunyai rerata suhu dan intensitas cahaya lebih tinggi dibanding dengan perlakuan naungan, sedangkan kelembapan dan $\mathrm{pH}$ lebih kecil. Hal ini akan mempengaruhi pola pertumbuhan tanaman planlet yang diaklimatisasi. Berikut ini persentase keberhasilan pertumbuhan aklimatisasi planlet stroberi pada berbagai perlakuan.

Tabel 2. Persentase daya tumbuh planlet stroberi pada berbagai perlakuan.

\begin{tabular}{lccc}
\hline \multirow{2}{*}{ Naungan } & \multicolumn{2}{c}{ Varietas } & \multirow{2}{*}{ Rerata Naungan } \\
\cline { 2 - 4 } & Lokal Berastagi & Dorit & \\
\hline Kontrol & $30 \pm 3,66 \mathrm{c}$ & $19 \pm 0,87 \mathrm{c}$ & $12,40 \mathrm{c}$ \\
Naungan $0,12 \mathrm{~mm}$ & $64,4 \pm 1,40 \mathrm{~b}$ & $59,47 \pm 1,10 \mathrm{~b}$ & $13,40 \mathrm{~b}$ \\
Naungan 0,17 mm & $85 \pm 2,00 \mathrm{a}$ & $69,26 \pm 1,10 \mathrm{a}$ & $12,76 \mathrm{a}$ \\
\hline Rerata Varietas & $66,47 \mathrm{a}$ & $49,24 \mathrm{~b}$ & \\
\hline
\end{tabular}

Pengamatan presentase tumbuh planlet stroberi menunjukkan bahwa presentase keberhasilan tumbuh pada aklimatisasi awal varietas lokal brastagi lebih tinggi dibandingkan dengan varietas dorit yaitu $85,2 \%$ hidup pada perlakuan Naungan 0,17 mm sedangkan varietas dorit 69,26\% hidup. Pada naungan ketebalan 0,12 mm sebesar 64,4 \% hidup varietas lokal brastagi dibanding 59,47 \%hidup varitas dorit. Sedangkan pada kontrol persentase yang hidup hanya $30 \%$ untuk lokal brastagi dan $19 \%$ untuk dorit.

Pada penelitian Elly, dkk (2012) mengenai pengaruh naungan dan varietas terhadap pertumbuhan dan hasil tanaman stroberi (Fragaria sp.) di dataran rendah menunjukkan bahwa pertumbuhan dan hasil terbaik terdapat pada tanaman stroberi yang ternaungi, penelitian pada taaman lainya menurut Rini, dkk. (2002) penelitian yang dilakukan oleh Sumarni dan Rosliani (2010) menunjukkan bahwa penggunaan naungan plastik transparan memberikan perbedaan pada hasil bobot umbi bawang merah dan memberikan pengaruh pada proses pertumbuhannya.

Setelah tanaman tumbuh pada aklimatisasi tahap pertama maka bibit yang tumbuh diperlakukan dengan penanaman dalam polibag besar dilapang. Berikut ini data pertumbuhan tanaman stroberi pada beberapa perlakuan.

Tabel 3. Hasil rerata jumlah daun pada perlakuan naungan dan varietas

\begin{tabular}{|c|c|c|c|}
\hline \multirow{2}{*}{ Naungan } & \multicolumn{2}{|c|}{ Varietas } & \multirow{2}{*}{ Rerata Naungan } \\
\hline & Lokal Berastagi & Dorit & \\
\hline Kontrol & $20 \pm 3,66$ & $9 \pm 0,87$ & $14,40 \mathrm{a}$ \\
\hline Naungan $0,12 \mathrm{~mm}$ & $14,4 \pm 1,40$ & $9,47 \pm 1,10$ & $12,40 \mathrm{a}$ \\
\hline Naungan $0,17 \mathrm{~mm}$ & $15 \pm 2,00$ & $9,26 \pm 1,10$ & $13,76 \mathrm{a}$ \\
\hline Rerata Varietas & $16,47 \mathrm{~b}$ & $9,24 \mathrm{a}$ & \\
\hline
\end{tabular}

Pada tabel 3 menunjukkan bahwa naungan yang diberikan tidak pengaruh signifikan pada jumlah daun. Namun secara jumlah perlakuan kontrol memberikan jumlah daun lebih banyak pada varietas lokal brastagi. Hal ini dikarenakan pada tumbuhan yang ternaungi mempunyai laju fotosintesis dan respirasi gelap yang sangat rendah sehingga tingkat kompensasi $\mathrm{CO} 2$ rendah saat cahayanya juga sangat rendah. Pada tanaman yang ternaungani cahaya biru meningkat relatif pada panjang gelombangnya tetapi perubahan kualitas paling jelas disebabkan oleh naungan yang meningkat pada cahaya merah jauh(Salisbury dan Ross, 1995). Naungan plastik sangat berpengaruh pada pemanjangan batang dan pertumbuhan kuncup samping pada berbagai tanaman (Salisbury dan Ross, 1995).Tanaman stroberi yang merupakan tanaman subtropis identik mempunyai 4 musim, suhu yang rendah, dan intensitas cahaya yang kurang (Gardner et al., 1993). Tanaman stroberi memiliki jumlah stomata yang banyak sehingga mudah sekali terjadi transpirasi dan banyak kehilangan air dalam selnya (Kurnia, 2005), sehingga tanaman yang ternaungi akan menghambat transpirasi pada tanaman stoberi akibatnya kandungan air yang akan digunakan untuk fotosintesis tetap tersedia didalam tanaman. 


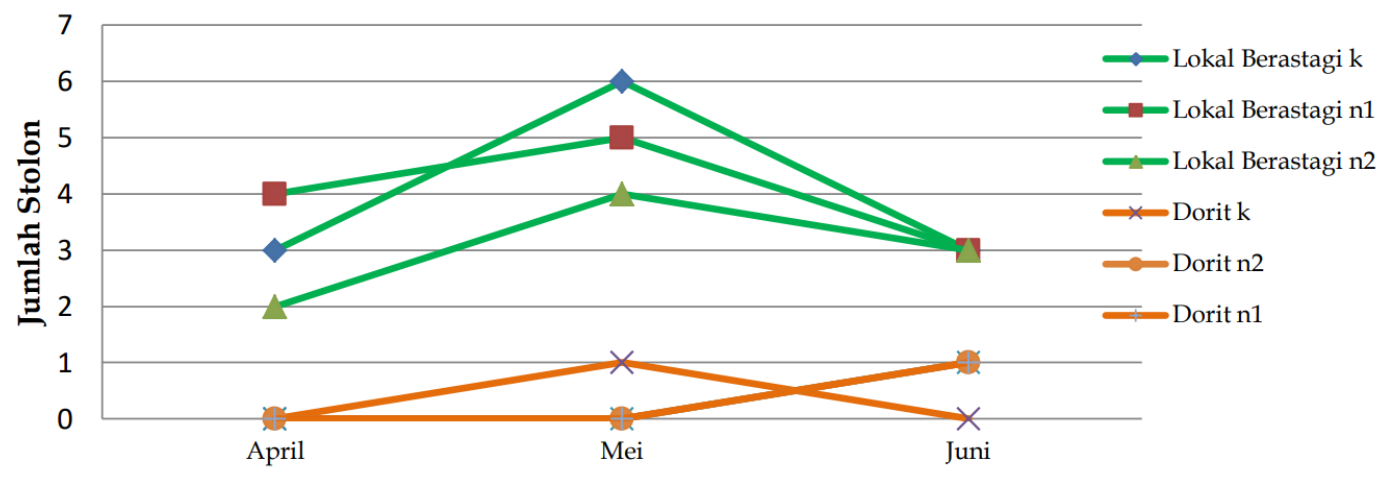

Gambar 1. Grafik jumlah daun stroberi selama 3 bulan pada beberapa perlakuan

Pada Gambar 1 menunjukkan pertumbuhan tanaman stroberi. Naungan dengan ketebalan naungan 0,17 mm dan 0,12 mm pertumbuhan vegetatifnya kurang baik dibandingkan dengan tanpa naungan pada varietas Lokal Berastagi hal ini dikarenakan varietas Berastagi merupakan tanaman hari netral yang tidak terpengaruh oleh panjang penyinarannya, sehingga walaupun naungan $0,17 \mathrm{~mm}$ yang intensitas cahayanya rendah varietas Berastagi tetap dapat bertahan sedangkan pada tanaman stroberi varietas Dorit naungan terbaik pada ketebalan 0,17 mm dibandingkan dengan naungan $0,12 \mathrm{~mm}$. Hal ini dikarenakan varietas Dorit merupakan tanaman hari pendek (Izsak dan Izhar, 1992) yang dipengaruhi panjang penyinaran kurang dari 12 jam, sehingga varietas Dorit tersebut lebih baik diberi naungan daripada tanpa naungan, hal ini sesuai dengan penanaman tanaman stroberi yang merupakan tanaman C3 yang mempunyai ciri aktivitas fotosintesisnya akan mengalami peningkatan jika intensitas cahayanya rendah. Stroberi varietas Lokal Berastagi yang paling baik tanpa naungan dibandingkan dengan perlakuan yang lain, hal ini menurut Dolyna (2008) tanaman stroberi yang ditanam di lapang menunjukkan pertumbuhan vegetatif yang paling baik.

Proses pembentukan daun membutuhkan suhu lingkungan antara 22 dan daun akan dibentuk setiap 8-12 hari (Kurnia, 2005). Berdasarkan data pendukung yang didapatkan dari ketiga waktu pagi, siang dan sore, suhu pagi hari rata-rata 26-28, suhu siang hari 38-41 dan sore hari antara 22-25. Berdasarkan suhu yang berfluktuasi dari pagi sampai sore, dari ketiga waktu tersebut waktu sore hari suhu untuk pembentukan daun. Daun yang terbentuk akan digunakan untuk melakukan fotosintesis sebagai sumber energi.

Selain daun, stolon merupakan parameter pertumbuhan vegetatif. Stolon merupakan merupakan perpanjangan tunas yang tumbuh horizontal sejajar dengan permukaan tanah (menjalar) yang merupakan organ perbanyakan vegetatif dan bibit yang berasal dari stolon akan cepat berbuah dan sifatnya sama dengan induknya (Kurnia, 2005). Pembentukan stolon paling banyak terbentuk dalam fase vegetatif dan jumlah menurun saat fase generatif. Pertumbuhan stolon ini akan mengakibatkan persaingan asimilat pada organ tanaman lainnya seperti pembentuk akar, batang dan daun (Prihadi, 2001).

Varietas Berastagi yang paling banyak menghasilkan stolon karena karakteristik Berastagi yang menghasilkan stolon tinggi, sedangkan jumlah stolon Dorit tidak terlalu banyak. Varietas Lokal Berastagi pertumbuhan vegetatifnya lebih baik dibandingkan dengan Dorit karena Lokal Berastagi merupakan tanaman hari netral yang tidak terpengaruh oleh intensitas cahaya yang dibutuhkan oleh tanaman.

\section{Jumlah Bunga}

Jumlah bunga dihitung dari penanaman bulan April sampai Juni. Hasil analisis varian pada taraf signifikan 5\% menunjukkan bahwa varietas berpengaruh signifikan hasil $\mathrm{F}$ value $<0,05$ dengan $\mathrm{F}$ value $>\mathrm{F}$ tabel $(7,22 ; 4,96)$. Naungan dan interaksi varietas dan naungan tidak berpengaruh signifikan karena $\mathrm{F}$ value $>$ 0,05. Hasil uji Duncan menunjukkan bahwa jumlah bunga varietas Berastagi berbeda nyata dengan varietas Dorit. Pada perlakuan kontrol tanpa naungan tidak berbeda nyata dengan naungan 0,12 mm dan $0,17 \mathrm{~mm}$. Naungan 0,12 mm tidak berbeda nyata dengan naungan $0,17 \mathrm{~mm}$. Rerata jumlah bunga pada bulan Juni dapat dilihat pada tabel 4 .

Tabel 4. Hasil rerata jumlah bunga perlakuan perbedaan naungan dan varietas

\begin{tabular}{lccc}
\hline \multirow{2}{*}{ Naungan } & \multicolumn{2}{c}{ Varietas } & \multirow{2}{*}{ Rerata Naungan } \\
\cline { 2 - 4 } & Lokal Berastagi & Dorit & $9,60 \mathrm{~b}$ \\
Kontrol & $12,27 \pm 3,90$ & $6,93 \pm 1,30$ & $7,90 \mathrm{ab}$ \\
Naungan 0,12 mm & $8,47 \pm 0,94$ & $7,33 \pm 0,94$ & $6,37 \mathrm{a}$ \\
Naungan 0,17 mm & $7,20 \pm 1,60$ & $5,53 \pm 1,60$ & \\
\hline Rerata Varietas & $9,31 \mathrm{~b}$ & $6,60 \mathrm{a}$ & \\
\hline
\end{tabular}

Proceedings homepage: https://conferenceproceedings.ump.ac.id/index.php/pspfs/issue/view/9 
Berdasarkan Tabel 4. varietas Berastagi jumlah bunga lebih banyak pada perlakuan kontrol dibandingkan naungan yaitu sebanyak 12,27 yang terendah adalah perlakuan naungan $0,17 \mathrm{~mm}$ sebanyak 7,20. Varietas Dorit yang paling banyak menghasilkan bunga pada perlakuan naungan $0,12 \mathrm{~mm}$ sebanyak 7,33 dan yang paling sedikit bunga yang dihasilkan pada naungan $0,17 \mathrm{~mm}$.

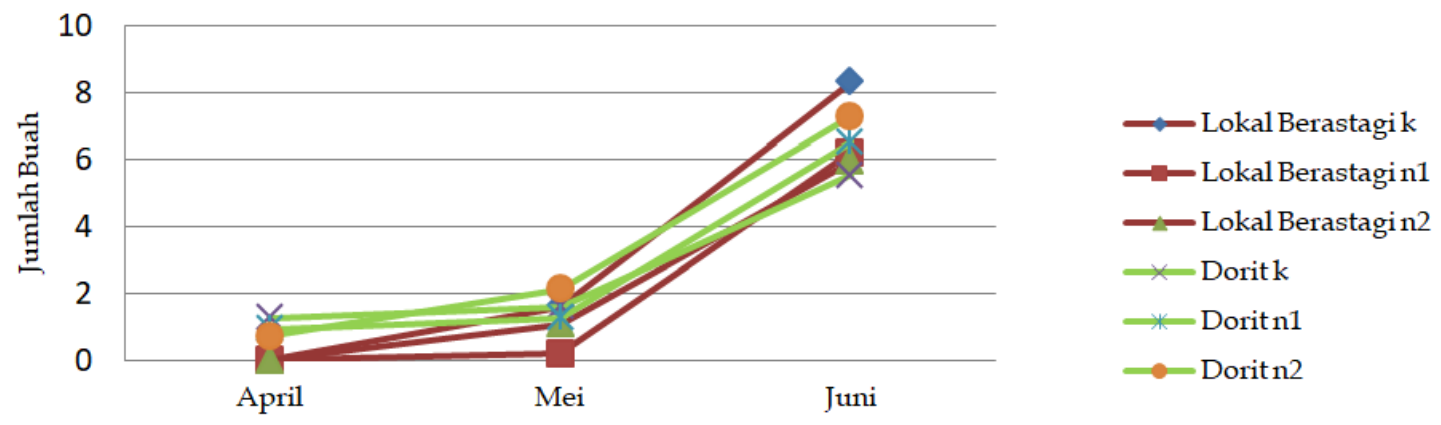

Gambar 3. Grafik pengaruh naungan dan varietas terhadap jumlah bunga

Berdasarkan Gambar 3 varietas Berastagi dengan garis berwarna biru menunjukkan bahwa jumlah bunga mengalami peningkatan dari semua perlakuan. Jumlah bunga yang paling banyak dihasilkan pada perlakuan kontrol tanpa naungan dibandingkan naungan $0,12 \mathrm{~mm}$ dan naungan $0,17 \mathrm{~mm}$. Varietas Dorit dengan garis berwarna merah menunjukkan jumlah bunga yang mengalami peningkatan pada semua perlakuan yang diberikan dan jumlah bunga yang paling banyak dihasilkan pada perlakuan naungan 0,12 mm. Hal ini menunjukkan bahwa intensitas cahaya yang banyak mampu memacu tingkat pembungaan tanaman stroberi lebih tinggi dibanding perlakuan pemberian naungan.

\section{Jumlah Buah}

Hasil analisis varian pada taraf sigifikan $5 \%$ menunjukkan bahwa varietas, naungan, interaksi varietas dengan naungan tidak berbeda nyata karena $F$ value $>0,05$. Hasil rerata jumlah buah pada bulan Juni dapat dilihat pada tabel dibawah ini.

Tabel 5. Hasil rerata jumlah buah pada perlakuan perbedaan naungan dan varietas

\begin{tabular}{lccc}
\hline \multirow{2}{*}{ Naungan } & \multicolumn{2}{c}{ Varietas } & \multirow{2}{*}{ Rerata Naungan } \\
\cline { 2 - 3 } & Lokal Berastagi & Dorit & $6,93 \mathrm{a}$ \\
Kontrol & $8,33 \pm 2,08$ & $5,53 \pm 1,27$ & $6,36 \mathrm{a}$ \\
Naungan $0,12 \mathrm{~mm}$ & $6,20 \pm 1,58$ & $6,53 \pm 0,92$ & $6,63 \mathrm{a}$ \\
Naungan $0,17 \mathrm{~mm}$ & $5,93 \pm 1,92$ & $7,33 \pm 1,17$ & \\
\hline Rerata Varietas & $6,82 \mathrm{a}$ & $6,47 \mathrm{a}$ & \\
\hline
\end{tabular}

Berdasarkan tabel 5 dan gambar 4. varietas Berastagi menghasilkan jumlah buah lebih banyak dibandingkan dengan varieta Dorit. Kelompok kontrol tanpa naungan pada varietas Berastagi jumlah buah yang dihasilkan paling banyak sebesar 8,33 dan terendah perlakuan naungan 0,17 mm sebesar 5,93. Varietas Dorit memberikan respon hasil jumlah buah yang berbeda, pada perlakuan naungan $0,17 \mathrm{~mm}$ menghasilkan paling banyak sebesar 7,33 sedangkan yang paling sedikit adalah 5,53. Hal ini terjadi karena pada perlakuan kontrol menghasilkan jumlah bunga yang banyak dibanding dengan naungan yang berakumulasi menjadi bakal buah yang banyak.

\section{Kadar Sukrosa}

Hasil analisis varian pada taraf sigifikan $5 \%$ menunjukkan bahwa varietas, naungan, interaksi varietas dengan naungan tidak berbeda nyata karena $F$ value $>0,05$. Rerata kadar sukrosa pada bulan Juni yang dihasilkan pada tabel dibawah ini.

Tabel 6. Rerata kadar sukrosa (brix) pada perlakuan perbedaan naungan dan varietas

\begin{tabular}{lccc}
\hline \multirow{2}{*}{ Naungan } & \multicolumn{2}{c}{ Varietas } & \multirow{2}{*}{ Rerata Naungan } \\
\cline { 2 - 4 } & Lokal Berastagi & Dorit & $70,93 \mathrm{a}$ \\
Kontrol & $18,58 \pm 19,07$ & $16,28 \pm 12,19$ & $62,68 \mathrm{a}$ \\
Naungan $0,12 \mathrm{~mm}$ & $15,10 \pm 15,85$ & $14,73 \pm 9,17$ & $57,57 \mathrm{a}$ \\
Naungan $0,17 \mathrm{~mm}$ & $15,96 \pm 21,19$ & $14,50 \pm 23,92$ & \\
\hline Rerata Varietas & $16,55 \mathrm{a}$ & $14,90 \mathrm{a}$ & \\
\hline
\end{tabular}


Berdasarkan Tabel 6. menunjukkan bahwa kadar sukrosa yang paling tinggi pada varietas Berastagi yaitu perlakuan kontrol (tanpa naungan) sebesar 18,58 dan kadar sukrosa terendah pada perlakuan naungan 0,12 mm sebesar 15,10. Pada varietas Dorit kadar sukrosa yang paling tinggi pada perlakuan naungan $0,17 \mathrm{~mm}$ sebesar 16,40 dan perlakuan kontrol tanpa naungan kadar sukrosa yang paling rendah sebesar 16,28.

Tanaman yang ternaungi luas daun bertambah disebabkan karena kecepatan difusi CO2 lebih tinggi, lebih banyak klorofil per unit satuan luas daun dan peningkatan aktivitas bagian-bagian yang melaksanakan fotosintesis (Fitter dan Hay, 1992). Aktivitas cahaya yang rendah akan mengakibatkan tanaman melakukan suatu perubahan fisiologis. Perubahan fisiologis ini memberikan dampak untuk pertahanan keseimbangan karbon yang akan mempengaruhi perubahan kecepatan respirasi. Pada tanaman yang ternaung ada 3 hal yang dilakukan dengan intensitas cahaya yang rendah, yaitu dengan cara pengurangan kecepatan respirasi untuk menurunkan titik kompensasi, titik kompensasi merupakan penggunaan $\mathrm{CO} 2$ oleh fotosintesis sama dengan hilangannya $\mathrm{CO} 2$ yang dihasilkan dari respirasi, peningkatan luas daun untuk mendapatkan satu permukaan yang lebih besar untuk mengabsopsi cahaya dan terjadi peningkatan kecepatan fotosintesis pada setiap unit energi cahaya dan luas daun (Fitter dan Hay, 1992).

\section{KESIMPULAN}

Berdasarkan data penelitian dan pembahasan dapat disimpulkan Naungan berpengaruh terhadap persentase pertumbuhan aklimatisasi planlet dan juga vegetatif stroberi varietas Dorit dan varietas Lokal Berastagi. Perlakuan terbaik adalah naungan plastik ketebalan $0,17 \mathrm{~mm}$ pada varietas Lokal Berastagi dengan daya tumbuh $85 \%$, Perlakuan kontrol tanpa naungan memberikn respon jumlah daun, bunga, jumlah buah dan kadar brix yang lebih tinggi dibanding perlakuan naungan untuk varietas lokal brastagi pada perlakuan, sedangkan pada Varietas dorit pada naungan $0,17 \mathrm{~mm}$.

\section{DAFTAR PUSTAKA}

Dolyna HMD, 2008. Pengaruh Lingkungan Tumbuh Yang Berbeda Terhadap Kualitas. Buah Stroberi. Skripsi. Dipublikasikan. Bogor: Institut Pertanian Bogor.

Elly K, Hayati dan Thamrin, 2012. Pengaruh Naungan dan Varietas Terhadap Pertumbuhan dan Hasil Tanaman Stroberi (Fragaria sp.) di Dataran Rendah. Jurnal Agrista, Vol.16 No.1.

Fitter AH dan RKM Hay, 1992. Fisiologi Lingkungan Tanaman. Yogjakarta: Gajah Mada University Press.

Gardner VR, FC Bradford dan HD Hooker, 1993. The Fundamental of Fruit Production. McGraw Hill Book Co.Inc. New York 778 p.

Harjadi SS, 1989. Dasar - Dasar Hortikultura. Departemen Budidaya Pertanian: Fakultas Pertanian IPB.

Izsak E, Izhar S, 1992. Strawberry Plant Dorit. United States Patent. State of Israel, Ministry of Agriculture, The Volcani Center, Bet Dagan, Israel.

Kurnia A, 2005. Petunjuk Praktis Budaya Stroberi. Jakarta: Agro Media Pustaka.

Muhsanati, Reni M dan Tari GPS, 2009. Pengaruh Pemberian Naungan Terhadap Pertumbuhan dan Hasil Tanaman Stroberi (Fragaria x annasa). Jurnal Jerami, Vol. 2 No.1.

Prihadi EM, 2001. Pengaruh Pemangkasan Cabang dan Penjarangan Bunga Jantan terhadap Pertumbuhan dan Produksi Ketimun dengan Budidaya Hidroponik. Skripsi. Bogor: Jurusan Budidaya Pertanian Fakultas Pertanian Institut Pertanian Bogor.

Rini R, Nani S dan Suwandi, 2002. Pengaruh Kerapatan Tanaman, Naungan, dan Mulsa terhadap Pertumbuhan dan Produksi Umbi Bawang Merah Mini Asal Biji. Jurnal Hortikultura. 12(1):28-34.

Salisbury FB dan Cleon WR, 1995. Fisiologi Tumbuhan Jilid 3. Bandung: ITB Bandung.

Soemadi W, 1997. Budidaya Stroberi di Pot dan Kebun. Solo: CV.Aneka Solo.

Sumarni N dan Rosliani R, 2010. Pengaruh Naungan Plastik Transparan, Kerapatan Tanaman, dan Dosis N terhadap Produksi Umbi Bibit Asal Biji Bawang Merah. Jurnal Hortikultura, 20(1):52-59, 2010. 